Agro-Science Journal of Tropical Agriculture, Food, Environment and Extension Volume 8 Number 3 September 2009 pn. 162-168

ISSN 1119-7455

\title{
NUTRIENT COMPOSITION AND ORGANOLEPTIC ATTRIBUTES OF GRUEL BASED ON FERMENTED CEREAL, LEGUME, TUBER AND ROOT FLOUR
}

\author{
Onoja, U.S. and Obizoba, I C ., \\ Department of Home Science, Nutrition and Dietetics,University of Nigeria, Nsukka, Nigeria .
}

\begin{abstract}
The nutrient composition and organoleptic attributes of gruel based on blends of 24-hour fermented wateryam (WY), cocoyam (CY), plantain (PT), african yam- bean $(A Y B)$, cowpea $(C P)$, pigeon pea $(P P)$ and corn $(C)$ flour were examined. A batch of each food-grain was picked clean, sun-dried, hammermilled into flour(40mm mesh screen) and put in polyethylene bag. Root, tuber and plantain were first peeled, sliced, sun-dried and milled into flour(40mm mesh screen) and also put in polyethylene bag. The flour batches were separately put in a container and were subjected to natural fermentation in de-ionized water in the ratio of 1:3 (w/v) at $28 \pm 2^{0} \mathrm{C}$ for 24 hours as pilot studies indicated that fermenting beyond this period produced off-odour in tuber, root and plantain. The fermented samples were dried at $55 \pm 2^{0} \mathrm{C}$ in a drought air oven (Gallenkamp, BS Model 250 size $2 \mathrm{UK}$ ), hammer milled into fine flour (70mm mesh screen) and stored in a refrigerator $\left(5 \pm 2^{\circ} \mathrm{C}\right)$ until used for the chemical analysis and production of gruels. The nutrients of the flour were determined by standard methods. The flour was blended in a ratio of 70: 30 to prepare various gruels on protein basis. Legume flour formed $70 \%$ of the blends. The C, WY, CY, PT flour formed the other 25, 5, 3 and $2 \%$ of the blends, respectively. Corn flour traditionally used to make gruels served as the control. The nutrient levels and organoleptic attributes of the gruels were evaluated using standard methods. The data was statistically analyzed using means, standard error of the means and Duncan's multiple range test to separate and compare means. Fermentation caused increases in various nutrients. African yam-bean, cowpea, pigeon pea, water-yam and cocoyam flour had increases in protein due to fermentation except for corn and plantain. It increased fat only in AYB, CY and PT. Ash and fibre were decreased in all the flour samples due to fermentation. The results showed that the gruel samples made from fermented blends contained various proportions of nutrients that ranged from 18.24 - $21.34 \%$ protein, $1.80-2.61 \%$ fat, $1.66-2.86 \%$ ash and 73.98 - $77.14 \%$ carbohydrate. The mineral levels were moderate except for phosphorus and calcium that ranged from $360-626 \mathrm{mg}$ and $318.20-376.60 \mathrm{mg}$, respectively. The $\mathrm{CP}_{24} \mathrm{C}_{24} \mathrm{CY}_{24} \mathrm{PT}_{24}$ blend had the highest nutrients except for fat, carbohydrate and copper as against other test blends. The blend that had the highest nutrients had the highest organoleptic attributes. As judged by the results, the blend that had high food potentials could be used as complementary foods.
\end{abstract}

Keywords: Gruel, nutrient composition, fermented blends, organoleptic test, cocoyam, Xanthosoma sagittifolium.

\section{INTRODUCTION}

The global emphasis is shifting from the traditional cereal - legume based foods to that of tubers and roots (Akobundu and Hoskins, 1987, Adeyemi 1993; FAO/WHO) (1994,2001).Oke and Adeyemi (1991) recognized the world food crisis and advocated for alternative sources for infant and adult food production. The prospects of blending tubers, roots and plantain with cereals and legumes for the production of household food products is receiving considerable attention worldwide (Chinsman, 1982; Okeke and Obizoba, 1986; Nnam , 2002). The products would be relatively cheap, nutritious and affordable to the rural poor to stem-off protein- energymalnutrition [PEM].

The nutrient composition of water-yam (Dioscorea alata) and cocoyam (Xanthosoma sagittifolium) is of nutritional importance. The protein content is between 1.2-to $2 \%$ and is low in sulphur containing amino acids (SAA). There are 
copious data in literature on the nutritional value of cereal-legume based household food products ( Mensah and Tomkins, 2003; Ahn et al., 2005; Hotz and Gibson, 2007). Scanty information exists on the combination and use of water-yam (Dioscorea alata) and cocoyam (Xanthosoma sagittifolium) and plantain(Musa paradisiaca) with cereals and legumes for the production of adult and children food products.

The presence of antinutrients and food toxicants limit the full utilization of cereallegume based food mixtures by humans (Hsu et al., 2006). This is because the foods are unprocessed to reduce food toxicants and other antinutrients to safe levels. Fermentation, dehulling, drying and milling are economic domestic food processing techniques used at homes to improve and increase nutrient density, acceptability, quality, availability, flavour, aroma and palatability (Wang, 1968; Beuchat and Worthington, 1974; Odunfa, 1985; Hotz and Gibson, 2007 ). They reduce bulk, viscosity and antinutrients ( Nnam, 2002).

Wateryam and cocoyam are produced abundantly in the eastern states of Nigeria. A greater percentage is wasted through post harvest losses. The application of these domestic food processing techniques would increase farm production of these lesser-utilized food materials and guarantee steady domestic and industrial production of these composites and their utilization.. The thrust of the work was to produce composite based on a 24-hour fermented wateryam, African yam-bean, cocoyam, plantain, cowpea, pigeon pea and corn. Analyze nutrient content of the composites, products and organoleptic attributes and general acceptability of the gruels/porridges

\section{MATERIALS AND METHODS}

\section{Materials.}

Water-yam (Dioscorea alata), cocoyam (Xanthosoma sagittifolium), plantain (Musa paradisiaca), African yam-bean (Sphenostylis stenocarpa), cowpea (Vigna unguiculata), pigeon pea (Cajanus cajan) and corn (Zea mays) were purchased from Eke-Ozzi market in Igbo-Eze North local government area of Enugu state, Nigeria.

\section{Processing of food}

Two kilogrammes $(2 \mathrm{~kg})$ of each of the 6 batches of different food materials were separately cleaned and used for the study. A batch of each food-grain was picked clean, sun-dried, hammermilled into flour(40mm mesh screen) and put in polyethylene bag. Root, tuber and plantain were first peeled, sliced, sun-dried and milled into flour(40mm mesh screen) and also put in polyethylene bag. The flour batches were separately put in a container and were subjected to natural fermentation in de-ionized water in the ratio of $1: 3(\mathrm{w} / \mathrm{v})$ at $28 \pm 2^{0} \mathrm{C}$ for 24 hours as pilot studies indicated that fermenting beyond this period produced off-odour in tuber, root and plantain. The fermented samples were dried at 55 $\pm 2^{0} \mathrm{C}$ in a drought air oven (Gallenkamp, BS Model 250 size $2 \mathrm{UK}$ ), hammer milled into fine flour (70mm mesh screen) and stored in a refrigerator $\left(5 \pm 2^{0} \mathrm{C}\right)$ until used for the chemical analysis and production of gruels.

\section{Formulation of composites.}

The protein of each flour and their blends was estimated using microKjeldahl procedure (1995). The composites were based on a ratio of 70:30 (protein basis) as shown below.

$\mathrm{AYB}_{24} \mathrm{C}_{24} \mathrm{WY}_{24}$ : African yam-bean, corn, wateryam 70:25:5

$\mathrm{CP}_{24} \mathrm{C}_{24} \mathrm{WY}_{24}$ : cowpea, corn, water-yam 70:25:5

$\mathrm{PP}_{24} \mathrm{C}_{24} \mathrm{WY}_{24}$ : pigeon pea, corn, water-yam $70: 25: 5$

$\mathrm{CP}_{24} \mathrm{C}_{24} \mathrm{CY}_{24} \mathrm{PT}_{24}$ : cowpea, corn, cocoyam, plantain 70:25:3:2

Where $A Y B_{24}:=24$-hour fermented african yambean, $C_{24}:=24$-hour fermented corn, $W Y_{24}:=24$ hour fermented water-yam, $\mathrm{CP}_{24:}=24$-hour fermented cowpea, $P_{24}:=24$-hour fermented pigeon pea, $C Y_{24:}:$ 24-hour fermented cocoyam, $P T_{24:}=24$ hour fermented plantain

\section{Preparation of gruels/porridges}

Gruels were prepared from different blends. The control was corn flour. A paste of each flour blend was made with cold water. Boiling water was added and stirred over fire until a desired consistency was obtained. Sugar was added to taste (optional). The control was prepared using the same procedure as for the test gruels.

\section{Sensory evaluation}

A nine-point hedonic scale (Derek and Richard,1984) was adopted. Nine represented the highest score and 1 the least in testing the organoleptic attributes of the gruels as well as general acceptability.

A 40- judge panel was randomly selected from students and lecturers of the Department of Home Science, Nutrition \& Dietetics to participate in the tasting sessions. The laboratory 
of the Department of Home Science, Nutrition and Dietetics, University of Nigeria, Nsukka was used for tasting.. The gruels were properly coded and served the panelists to evaluate for flavour, colour, texture and general acceptability. Each judge was offered a glass of water to rinse mouth so as to prevent carry-over effect after each tasting.

\section{Chemical analysis}

The proximate composition of the flour was determined using standard methods (AOAC,1995). The gruels were analyzed for proximate and minerals using standard procedures. All analyses were performed in triplicates. The microKjeldahl method was used to estimate the protein content. Ash was estimated by incinerating $1 \mathrm{~g}$ of the sample between 550$600^{\circ} \mathrm{C}$ for $6 \mathrm{~h}$ in a muffle furnace until ash was obtained. Lipid was extracted with petroleum ether using Tecator Soxhtec apparatus. The carbohydrate was obtained by difference. Mineral was determined by wet digestion with nitric and perchloric acids. The values were read in Atomic Absorption Spectrophotometer. In order to correct for the variability from different moisture levels, residual moisture was determined in all the samples. With this, therefore, a factor $(F)$ was computed which enabled all calculations to be done on dry matter basis. Thus $\mathrm{F}=100 / 100-$ moisture content (determined) (FAO, 1994).

\section{Statistical analysis}

Means, standard deviation of the data were calculated. Analysis of variance (ANOVA) and Duncan's New Multiple Range Tests (DNMRT) were used to separate and test differences among means (Snedecor and Cochran, 1956; Steel and Torrie, 1960).

\section{RESULTS}

The proximate composition of the fermented and unfermented flour is presented in Table1. The 24-hour fermentation increased protein in African yam-bean, cowpea, pigeon pea, water-yam and cocoyam when compared with their controls. It decreased protein in corn and plantain. It caused slightest increase in water-yam protein (4.64 vs $4.63 \%$ ). Fermentation increased fat in AYB, cocoyam and plantain. It decreased lipid in cowpea, pigeon pea, corn and water-yam. Both ash and fibre were decreased by the 24-hour fermentation in all samples. Carbohydrate was increased in all food except for plantain. .
Table 2 depicts the nutrient composition of the gruels. The protein values for the gruels varied. The range was from 8.46 to $21.34 \%$. The $\mathrm{CP}_{24} \mathrm{C}_{24} \mathrm{CY}_{24} \mathrm{PT}_{24}$ composite had the highest protein $(21.34 \%)$ and the $100 \%$ corn flour had the least $(8.46 \%)$. The fat content of the gruels ranged from 1.80 to $4,26 \%$. The $\mathrm{PP}_{24} \mathrm{C}_{24} \mathrm{WY}_{24}$ and the $\mathrm{CP}_{24} \mathrm{C}_{24} \mathrm{CY}_{24} \mathrm{PT}_{24}$ gruels had the least and comparable fat (1.80 and $1.82 \%$, respectively). These two gruels on the other hand, had significantly higher $(\mathrm{P}<0.05)$ ash levels compared to the other blends and the control. The control sample had the highest carbohydrate $(87.20 \%)$ as against the test samples $(\mathrm{P}<0.05)$. The $\mathrm{PP}_{24} \mathrm{C}$ ${ }_{24} \mathrm{WY}_{24}$ had the highest carbohydrate $(77.14 \%)$ among the test blends but was not significantly different $(\mathrm{P}>0.05)$ from the other test samples. The $\mathrm{AYB}_{24} \mathrm{C}_{24} \mathrm{WY}_{24}$ had the second highest (76.37\%) while $\mathrm{CP}_{24} \mathrm{C}_{24} \mathrm{CY}_{24} \mathrm{PT}_{24}$ blend had the least $(73.98 \%)$. The control sample had the least $\mathrm{Cu}(0.02 \mathrm{mg})$ while $\mathrm{CP}_{24} \mathrm{C}_{24} \mathrm{WY}_{24}$ had the highest $\mathrm{Cu}$ level $(0.06 \mathrm{mg})$ compared to the others but the difference was not significant $(\mathrm{P}>0.05)$. The $\mathrm{AYB}_{24} \mathrm{C}_{24} \mathrm{WY}_{24}$ and $\mathrm{CP}_{24} \mathrm{C}_{24} \mathrm{CY}_{24} \mathrm{PT}_{24}$ blends had comparable values $(0.04 \mathrm{mg}$ vs $0.04 \mathrm{mg})$. The $\mathrm{PP}_{24} \mathrm{C}_{24} \mathrm{WY}_{24}$ had $(0.03 \mathrm{mg}) \mathrm{Cu}$. On the other hand, the control had the highest Fe concentration $(2.46 \mathrm{mg})$ compared to the test samples $(\mathrm{P}<0.05)$. The $\mathrm{CP}_{24} \mathrm{C}_{24} \mathrm{CY}_{24} \mathrm{PT}_{24}$ had the highest $\mathrm{Fe}$ $(0.75 \mathrm{mg})$ followed by $\mathrm{AYB}_{24} \mathrm{C}_{24} \mathrm{WY}_{24}(0.59 \mathrm{mg})$ among the test gruels. The $\mathrm{CP}_{24} \mathrm{C}_{24} \mathrm{WY}_{24}$ and $\mathrm{PP}_{24} \mathrm{C}_{24} \mathrm{WY}_{24}$ had comparable values $(0.46 \mathrm{mg}$ vs $0.45 \mathrm{mg}$, respectively). The $\mathrm{CP}_{24} \mathrm{C}_{24} \mathrm{CY}_{24} \mathrm{PT}_{24}$ blend had the highest phosphorus $(626 \mathrm{mg})$ when compared to the other blends and the control $(\mathrm{P}<0.05)$. The values ranged from $(196 \mathrm{mg}-$ $626 \mathrm{mg}$ ). The control had the least P level (196mg) which differed markedly $(\mathrm{P}<0.05)$ from the test gruels. The $\mathrm{CP}_{24} \mathrm{C}_{24} \mathrm{CY}_{24} \mathrm{PT}_{24}$ gruel had the highest calcium $376.60 \mathrm{mg}$ as against the other test samples. The control sample had the least (314mg). The values for the test samples ranged from (318.20mg - 376.60mg).

The organoleptic attributes of the gruels are presented in Table 3. The control had the highest organoleptic attributes when the values were summed up than the other test gruels (33.30) followed by that of the $\mathrm{CP}_{24} \mathrm{C}_{24} \mathrm{CY}_{24} \mathrm{PT}_{24}$ blend (32.96). However, the $\mathrm{CP}_{24} \mathrm{C}_{24} \mathrm{CY}_{24} \mathrm{PT}_{24}$ gruel had slightly higher acceptability (8.80) than the control (8.70). The gruel that contained AYB and PP had the least summed values (22.08 and 24.10, respectively). The gruels that contained $\mathrm{CP}$ had the first and second highest values (32.96 and 27.16) as against the control (33.30). 
Table 1 Nutrient composition of 24-hour fermented and unfermented African yam-bean (AYB), cowpea (CP), pigeon pea (PP), corn (C), water-yam (WY), cocoyam (CY) and plantain (PT) flour (dry weight) $(\%)^{\mathrm{a}}$

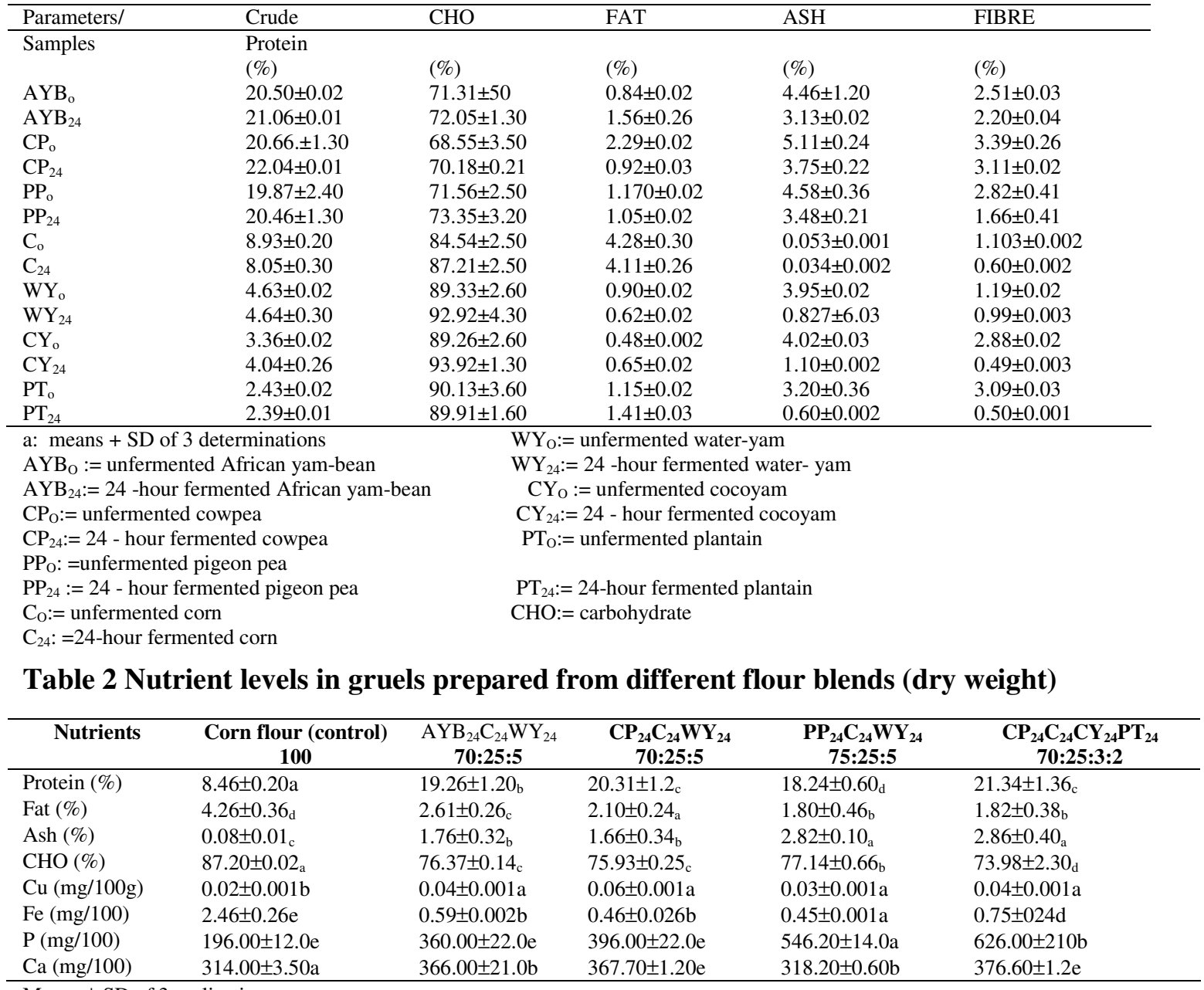

Means \pm SD of 3 replications

Values not followed by the same letters in the same horizontal line are significantly different $(\mathrm{P}<0.05)$.

$A B_{24}:=24$-hour fermented african yam- bean, $C_{24}:=24$-hour fermented corn, $W_{24}:=24$-hour fermented water-yam, $C_{24}:=$ 24-hour fermented cowpea, $\mathbf{P P}_{24}:=24$-hour fermented pigeon pea, $\mathbf{C Y}_{24:}:=24$-hour fermented cocoyam, $\mathbf{P T}_{24}:=24$-hour fermented plantain, $\mathrm{Cu}$ : =copper, Fe := iron. $\mathrm{P}:=$ phosphorus, Ca:= calcium.

Table 3: Organoleptic properties of gruels produced from blends of all vegetable sources (dry weight)

\begin{tabular}{|c|c|c|c|c|c|}
\hline Parameters/blends/ratios & $\begin{array}{l}\text { Corn flour } \\
\text { (control)100 }\end{array}$ & $\begin{array}{c}\mathrm{AYB}_{24} \mathrm{C}_{24} \mathrm{WY}_{24} \\
\mathbf{7 0 : 2 5 : 5}\end{array}$ & $\begin{array}{c}\mathrm{CP}_{24} \mathrm{C}_{24} \mathrm{WY}_{2} \\
{ }_{4} \mathbf{7 0 : 2 5 : 5}\end{array}$ & $\begin{array}{c}\mathrm{PP}_{24} \mathrm{C}_{24} \mathrm{WY}_{24} \\
75: 25: 5\end{array}$ & $\begin{array}{c}\mathrm{CP}_{24} \mathrm{C}_{24} \mathrm{CY}_{24} \mathrm{PT}_{24} \\
70: 25: 3: 2\end{array}$ \\
\hline Colour & $8.60 \pm 0.12_{\mathrm{a}}$ & $6.12 \pm 0.36_{b}$ & $6.76 \pm 0.42_{\mathrm{d}}$ & $7.10 \pm 0.38_{\mathrm{d}}$ & $7.86 \pm 0.32_{\mathrm{a}}$ \\
\hline Flavour & $8.40 \pm 0.34_{b}$ & $5.46 \pm 0.26_{c}$ & $7.40 \pm 0.56_{d}$ & $6.20 \pm 0.24_{c}$ & $8.50 \pm 0.18_{b}$ \\
\hline Texture & $7.60 \pm 0.13_{\mathrm{d}}$ & $5.50 \pm 0.34_{c}$ & $6.40 \pm 0.16_{\mathrm{d}}$ & $5.60 \pm 0.14_{b}$ & $7.80 \pm 0.20_{\mathrm{a}}$ \\
\hline General acceptability & $8.70 \pm 0.17_{b}$ & $5.10 \pm 0.28_{c}$ & $6.60 \pm 0.28_{\mathrm{d}}$ & $5.20 \pm 0.14_{\mathrm{e}}$ & $8.80 \pm 0.56_{\mathrm{f}}$ \\
\hline Total & 33.30 & 22.08 & 27.16 & 24.10 & 32.96 \\
\hline
\end{tabular}

Means \pm SEM of 40 judges.

values not followed by the same letter in the same horizontal line is statistically different $(\mathrm{P}<0.05)$

$\mathrm{AYB}_{24}:=24$-hour fermented african yam- bean, $\mathrm{C}_{24}:=24$-hour fermented corn, $\mathrm{WY}_{24}:=24$-hour fermented water-yam, $\mathrm{CP}_{24}:=24-$ hour fermented cowpea, $\mathrm{PP}_{24}:=24$-hour fermented pigeon pea, $\mathrm{CY}_{24:}:=24$-hour fermented cocoyam, $\mathrm{PT}_{24}:=24$-hour fermented plantain. 
Onoja, U.S. and Obizoba, I C .,

\section{DISCUSSION}

The increases in protein of foods fermented for twenty four hours is simple to explain. During fermentation, microflora enzymes hydrolyzed bonds among bound proteinantinutrient and enzyme to release free amino acids for synthesis of new protein(El-Hag et al.,2002; Mensah et al., 2003; Ahn,2005; Hotz and Gibson, 2007). On the other hand, the decreases in protein in corn and cocoyam might be that the fermenting microflora used it for metabolism or it leached into the fermentation media - a commonly observed phenomenon (Table 1). The decreases in fat of all foods except for AYB, cocoyam and pigeon pea might be that the fermentation microflora utilized fat as source of energy as well as carbohydrate (Odunfa, 1985). The foods that had increases in fat might be fat from dead microflora or the fermenting microflora did not use fat from these foods as source of energy. The decreases in ash for all the foods might be due to vegetative loss during fermentation. This could also be that it leached into the fermentation or microflora used it for metabolism (Reebe et al., 2000). The higher ash for the controls appears to suggest that minerals in these foods would be much more available than in the fermented samples. The least ash for corn $(0.05$ or $0.03 \mathrm{mg})$ is an indication that it is a poor source of mineral. Regardless of treatments, legumes are better sources of nutrients than cereals, tubers and roots. The loss of fibre in these foods was due to hydrolysis and leaching into fermentation medium or the microflora used it for metabolism (Odunfa, 1985; Okeke and Obizoba, 1986). The legumes also had higher fibre than the other foods (Table I). The slight increases in carbohydrate except for that of plantain was due to low moisture. It is well established that the higher the loss of moisture in a given food the higher is the dry matter and vice versa (Okeke and Obizoba, 1986).

The higher protein $(21.34 \%)$ for the $\mathrm{CP}_{24} \mathrm{C}_{24} \mathrm{CY}_{24} \mathrm{PT}_{24}$ (Table 2) as well as for the $\mathrm{CP}_{24} \mathrm{C}_{24} \mathrm{WY}_{24}$ blend (20.34\%) showed that cowpea had better mutual supplementation effect than African yam-bean and pigeon pea .On the other hand, the lower fat values for the $\mathrm{CP}_{24} \mathrm{C}_{24} \mathrm{WY}_{24}$, the $\mathrm{PP}_{24} \mathrm{C}_{24} \mathrm{WY}_{24}$ and $\mathrm{CP}_{24} \mathrm{C}_{24} \mathrm{CY}_{24} \mathrm{PT}_{24}$ suggested that these blends would have higher shelf-life as against the rest of the blends $(2.10,1.80$ and 1.82 vs 4.26 and $2.61 \%$,respectively) (Van- Veen and Stainkraus, 1970). The higher and comparable ash for the $\mathrm{PP}_{24} \mathrm{C}_{24} \mathrm{WY}_{24}$ and $\mathrm{CP}_{24} \mathrm{C}_{24} \mathrm{CY}_{24} \mathrm{PT}_{24} \quad\{2.82$ and 2.86) suggests that either is as good as the other as source of ash. The lower ash $(0.08 \mathrm{mg})$ for corn alone showed that it is a poor source of ash. However, when it is mixed with other foods , ash increased due to synergistic effects of other foods, from 0.08 to 2.82 and $2.86 \mathrm{mg}$,respectively (Table $2)$. The lower carbohydrate $(78.98 \%)$ for the $\mathrm{CP}_{24} \mathrm{C}_{24} \mathrm{CY}_{24} \mathrm{PT}_{24}$ blend might be its higher protein and lower fat values. The highest carbohydrate and fat $(87.20 \%$ and $4.26 \%)$ for the $100 \%$ corn gruel was not a surprise. Corn is high in fat and carbohydrate. The high phosphorus and calcium for all gruels showed that the gruels were good sources of minerals . However, the higher values $(546.20,626.00,318.20$, and $376.00 \mathrm{mg}$ ) for the $\mathrm{PP}_{24} \mathrm{C}_{24} \mathrm{WY}_{24}$ and $\mathrm{CP}_{24} \mathrm{C}_{24} \mathrm{CY}_{24} \mathrm{PT}_{24}$ blends showed their edge over the other blends. This edge might be due to much more synergism, desirable and better supplementary effects among each component (Reebe et al., 2000).

The higher organoleptic attributes of the control (33.30) when all the attributes were summed up and compared is simple to explain. The judges were familiar with corn gruel (porridge). On the other hand, the similarity in organoleptic attributes (33.30 and 32.96). between the control and the $\mathrm{CP}_{24} \mathrm{C}_{24} \mathrm{CY}_{24} \mathrm{PT}_{24}$ blend indicates that any of the gruels was equally liked. On the whole, the gruels were good because their attributes were more than one half $(50 \%)$ of the standard.scale (9 points). The judges had preference to colour and flavour of gruel from the $\mathrm{CP}_{24} \mathrm{C}_{24} \mathrm{CY}_{24} \mathrm{PT}_{24}$ blend over the other test samples. This was because of synergistic effects of food supplementation. The low colour and flavour scores for the $\mathrm{AYB}_{24} \mathrm{C}_{24} \mathrm{WY}_{24}$ and $\mathrm{PP}_{24} \mathrm{C}_{24} \mathrm{WY}_{24}$ blends was because of poor mutual supplementation effect, as well as the type of supplement. The general acceptability of the gruels was influenced by colour, flavour and texture. The $\mathrm{CP}_{24} \mathrm{C}_{24} \mathrm{CY}_{24} \mathrm{PT}_{24}$ blend and the control had better colour and flavour than other test blends. Based on this, they were much more acceptable. This is not surprising because it is known that appearance of food evokes the initial response and flavour determines the final acceptance or rejection of the product by the consumer (Nnam,2002; Teratanavat and Hooker, 2006). The higher acceptability of the $\mathrm{CP}_{24} \mathrm{C}_{24} \mathrm{CY}_{24} \mathrm{PT}_{24}$ blend was due to improved flavour as a result of fermentation and mutual supplementation effect of food nutrients. This blend contained plantain that might have contributed to the enhanced flavour. MbithiMwikya et al. (2002) reported higher acceptability of corn chips, rice chips and bakery products from fermented flour. Both fermentation and good 
mutual supplementation enhanced the nutritional quality and organoleptic attributes of the gruels.

Fermentation of tubers, roots, legumes, cereals and plantain would diversify their food use when incorporated into traditional dishes for those who preferred natural enhancement of nutrients to fortification.

\section{REFERENCE}

Adeyemi, I. A. (1993)."Cassava as an alternative raw material for weaning food manufacture in Nigeria". Product development from root and tuber crops IITA Annual Report Series Vol iii pp 7331.

Ahn, H.J, Kim, J.H. PKW. NG. (2005). Functional and thermal properties of wheat, barley and soy flours and their blends treated with a microbial transglutaminase. Journal of Food Science. 70: 380-386.

Akobundu, E.N.J and Hoskins,E.H. (1987). Potential of corn - cowpea mixture in infant food. Journal of Food and Agriculture 1: 111- 114.

Association of Official Analytical Chemists (AOAC) (1995). Official Methods of Analysis. Washington D.C.

Beuchat, L.R. and Worthington, R.E.(1974). Changes in the lipid content of fermented peanut. Journal. Agric Food Chemistry 22:509-512.

Chinsman, B. (1982). Technology Assessment and Choice. The case of root and tuber processing. In: Chinsman, B. (ed).Proceeding of the regional workshop on root and tuber production, storage, processing and marketing in Africa. African Regional Centre for Technol. Dakar, Senegal.

Hotz Christine and Gibson, R. S. (2007). Traditional food. processing and preparation practices to enhance the bioavailability of micro-nutrients in plant -based diets. Journal of Nutrition 137:1097-1100.

Cochran, W.C. and Cox, G.M. (1957). "Experimental Designs " 2 nd $e d$. John Wiley and Sons Inc.London.

Derek, G.L. and Richard, S. (1982) . Scaling and baking methods. In: Sensory analysis of food. Elsevier Appl. Sci Publishers. London, NY pp 157-155.

EI. Hag, M.E. EI- Tinay, A.H. Yousuf, N. (2002). Effect of fermentation and dehulling on starch, total polyhenols, phytic acid and in vitro protein digestibility of pearl millet. Journal of Food. Chemistry 77:193-196.

Food and Agriculture organization (FAO) (1994). "Grain legume conservation and processing". Report of FAO Expert Consultation on legume processing. UN. Rome, pp 1 - 16

Food and Agriculture Organization (FAO) of the United Nations (2001).

Targeting for nutrition improvement resources for advancing well being. Food and Nutrition Series. UN. Rome, Vol iv pp 1-18.

Hulse, J. H. (2004). Integrated food systems for food security in a changing world environment. Journal of Food Science 69: 130-134.

Hsu Cheng-Chin, Vi-Chia Huang, Mei-Yin, ShynJye Lin. (2006). Effect of yam (Dioscorea alata) compared to (Dioscorea japonica) on gastrointestinal function and anti-oxidant activity in mice. Journal of Food Science 71:5516 5521.

Janet, A. Foote, Sussane P, Murphy L.R, Wilkens, P, Peter, B. and Carlson. A. (2004). Dietary variety increases the probability of nutrient adequacy among adults. Journal of Nutrition 134: 1779-1785.

Mbithi-Mwikya S., Van comp, J. Mamiro, P.R., Osoghe W., Kolesteren, P, and Huyghebeart. A. (2002). Evaluation of the nutritional characterisitics of finger millet based complementary food. Journal of Agric Food Chemistry 50:3030-3036.

Nnam, N. M. (2002). Evaluation of complementary foods based on maize, ground nut, pawpaw and mango flour blend. Nigerian Journal of. Nutritional Sciences 23:1-4.

Odunfa, S.A. (1985). African fermented foods. In: Microbiology of fermented foods. J.B.Wood (ed). Elsevier Appl. Sci. Publ. London, NY.

Oke, O.L and Adeyemi, I.A. (1991). "Consumption of alternative flour in West Africa" Paper presented at the Eight World Congress of Food Science and Technol. Sept 29-Oct. 4. Toronto, Canada.

Okeke, E.C. and Obizoba, I.C. (1986). The nutritive value of all vegetable protein diets based on legume, cereal and tuber 
in weanling rats. Qual. Plant Food for Human Nutrition 36:213-222.

Reebe, S., Gonzalez, V.N and Rengifo, J. (2000). Research on trace elements in the common beans. Food. Nutr. Bull. 21:387-391.

Richard, F. Hurrel, M (2003). Influence of vegetable protein sources on trace element and mineral bio-availability. Journal of Nutrition. 133.29735-29775.

Snedecor, G.W. and Cochran, W.O. (1956). "Statistical Methods". The lowa state coll. press. Ames. IA p. 37.
Teratanavat, R .and Neal, H. H. (2006). Consumer valuations and preference heterogeneity for a novel functional food. Journal of Food Science 71:533-534.

Van- Veen, A. G and Steinkraus, K.H. (1970). Nutritive value and wholesomeness of fermented foods. J. Agric Food Chemistry 18:576-578.

Wang, H.L. (1968). Protein quality of wheat and soybeans after Rhizopus oligosporus fermentation. Journal of Nutrition 96:109- 112. 